\title{
NOT SO PARADOXICAL: THE RATIONALE FOR TECHNOLOGY-BASED REGULATION
}

\author{
SIDNEY A. SHAPIRO* \\ THOMAS O. MCGARITY**
}

\section{INTRODUCTION}

In Administrative Substance, Cass Sunstein invites us to study carefully the pathologies of regulation, and then to apply the lessons derived froun this study to the more difficult task of improving the substance of regulatory programs. ${ }^{1}$ Professor Sunstem is especially critical of "social" regulation that requires agencies to identify the best available technologies and to write standards that require individual regulatees to use those technologies. ${ }^{2}$ In particular, Sunstem rejects this strategy's presumption that all similarly situated regulatees are capable of meeting the standards of the best performers in the industry. ${ }^{3}$ Yet when we look at the same evidence that was marshalled by Sunstein, we draw a remarkably different conclusion: Congress's decision to order the reduction of toxic substances to the lowest poimt permitted by the "best available technology" (BAT) is rational, and stands up well when compared to the rehance on market-related regulation preferred by Sunstein. ${ }^{4}$ Although we agree with Sunstein that the technology-based approach to social regulation is far froin perfect, we will attempt to show how Sunstein undervalues technology-based health and safety legislation and overvalues the alternative market-related regulation. In the final analysis, some combination of approaches may prove most desirable in most regulatory contexts.

Our critique proceeds in three parts. First, in Part II, we contest Sunstein's calculations of "costs" and "benefits," and his conclusion that

* John M. Rounds Professor of Law, University of Kansas. B.S., 1970; J.D., 1973, University of Pennsylvania.

** William Stamps Farish Professor of Law, University of Texas. B.A., 1971, Rice University; J.D., 1974, University of Texas.

The authors would like to thank Professors Douglas Laycock, James Robinson, and Peter Strauss for their helpful comnients. Professor Shapiro's research was supported by the University of Kansas Research Fund.

1. See Sunstein, Administrative Substance, 1991 Duke L.J. 607.

2. See id. at 627-31.

3. See id. at 628.

4. See id. at 631-42 (advocating various nrarket-based regulatory strategies, including emissions trading and pollution taxes). 
stringent regulation causes underregulation. Second, in Part III, we argue that even when the employment of a technology-based regulation gives rise to costs that exceed benefits (as conventionally measured by economists) that regulation may be justified on normative grounds. Finally, im Part IV, we show that practical reasons can also justify regulatory programs that an economist would deem "inefficient." In particular, we suggest that although market-related regulation could play an important role in, for example, the control of toxic substances, this approach is not so demonstrably effective so as to warrant the abandonment of the technology-based approach.

\section{OVERREGULATION AND UNDERREGULATION}

Sunstein will have no part of the broad conservative critique that most government regulation is paternalistic, or at least inakes inatters worse, but he hastens to add that regulation has had its fair share of failures. ${ }^{5}$ This latter point, of course, is not a new one. In fact, Professor Breyer forcefully presented the problems of regulatory failure more than a decade ago im his important project for the American Bar Association Commission on Law and the Economy. ${ }^{6}$ Professor Sunstein's contribution to the substantive regulation debate hes in his observation that programs that have perforned poorly have done so along identifiable lines because of "regulatory paradoxes."7 One of these so-called regulatory paradoxes is the idea that strict regulation of toxic substances will actually result in less protection than more lement regulation. ${ }^{8}$ First expressed by Professor John Mendeloff im a recent critique of Occupational Safety and Health Adımistration (OSHA) regulation under the banner "overregulation causes underregulation,"9 this idea has an attractive ring to those, mcluding Sunstem, who have little sympathy for "coinunandand-control" regulatory programs. ${ }^{10}$ However, in this discussion, we dispute Mendeloff's (and presumably Sunstein's) conclusions that OSHA has engaged in overregulation and that the adoption of less stringent standards will increase OSHA's regulatory productivity. We begin first,

5. See id. at 625-27.

6. AmERican Bar Association, Commission on LAw aNd the Economy, Federal REGULATION: ROADS TO REFORM (Exposure Draft 1978). In this paper appeared partial or skeletal versions of the framework presented in S. BREYER, REGULATION AND ITS REFORM (1982).

7. See Sunstein, supra note 1 , at $629-30$.

8. See id. at 629.

9. J. Mendeloff, The Dilemma of Toxic Substances Regulation: How OverreguLATION CAUSES UNDERREgulation at OSHA 3 (1988). By "overregulation," Mendeloff means any regulation whose costs exceed its benefits, as economists conventionally measure those consequences. Id. at 24.

10. See Sunstein, supra note 1, at 627. 
however, by questioning Sunstein's foundation that costs and benefits can be (and have been) adequately computed.

\section{A. The Costs and Benefits of Strict Regulation}

Sunstein cites with approval Mendeloff's finding that only one of ten health standards proinulgated by OSHA-the asbestos standard-has a reasonable cost ( $\$ 400,000$ per life saved), whereas the other nine standards each cost millions of dollars and save only a few lives. ${ }^{11}$ Sunstein particularly emphasizes the vinyl chloride standard. ${ }^{12}$ That standard, according to Mendeloff, saves only one hife per year at a cost of $\$ 40$ million. ${ }^{13}$ However, Mendeloff's calculations of the costs and benefits of toxic substance regulation are subject to numerous sources of error, none of which appears to cause Sunstem any pause.

On the cost side, Mendeloff's principal problem is his rehance on cost estimates that are based, for the most part, on notoriously inaccurate before-the-fact predictions. ${ }^{14}$ Although Mendeloff recognizes the uncertainty that this problem introduces into his analysis, ${ }^{15}$ neither he nor Sunstein hesitate to make policy recommendations based on the assumption that these ex ante cost estimates proved accurate. Attempts to validate cost projections in light of subsequent experience have been sparse, but the evidence that does exist suggests that pre-implementation cost estimates are often far too high. ${ }^{16}$

The inadequacies of Mendeloff's cost estimates pale in comparison with his failure to grapple with the exceedingly coinplex and value-laden issues inherent in estinating or measuring health and environmental regulation's benefits. To begin with, current techniques for risk assessment simply do not have the power to permit anything approximating precise

11. See id. at 625 \& n.80; see also J. MENDELofF, supra note 9, at 22.

12. See Sunstein, supra note 1 , at 625 n. 80 .

13. See J. MENDELofF, supra note 9 , at 22.

14. For example, a former Department of Labor economist noted that the actual cost of complying with OSHA's vinyl chloride standard was only about seven percent of the predicted cost. See M. CONNERTON \& M. MACCARTHY, COST-BENEFIT ANALYSIS AND REgULATION: EXPRESSWAY TO REFORM OR BLIND ALLEY? 20 (1982) (citing study conducted by Industrial Research Unit of the Wharton School, published in H. NorTHRup, R. Rowan \& C. PERRY, THE IMPACT OF OSHA (1978)).

15. See J. Mendeloff, supra note 9, at 55-59.

16. See M. Green \& N. Waitzman, Business War on the Law: an analysis of the BenEFits of Federal HeAlth/SAfety ENFORCEMENT 54-55 (1979); M. CONNERTON \& M. MacCarthy, supra note 14, at 20 (citing Putnam, Hayes \& Bartletr, InC., Comparisons of Estimated and ACtual Pollution Control Capital EXPenditures for Selected IndusTRIEs (June 1980) (prepared for Office of Planning and Evaluation, U.S. Environmental Protection Agency)). 
calculations of the number of lives saved by a health or safety standard. ${ }^{17}$ For example, the predictions of cancer risk assessment models can vary over ten orders of magnitude. ${ }^{18}$ Translated into economic terms, the difference between some low and high estimates of cancer risk approximates the difference between the price of a cup of coffee and the national debt. ${ }^{19}$

The vinyl chloride standard, cited by Mendeloff as the worst example of overregulation, ${ }^{20}$ exemplifies the imprecision in risk ineasurement particularly well. In calculatimg that the vinyl chloride standard saves only one life per year, Mendeloff makes several assumptions that belittle the impact of the standard. In fact, given the uncertainties in the inforination and the primitive state of current knowledge about environmental carcinogenesis, an estimate of twenty or even forty lives per year saved by the vinyl chloride standard would be equally plausible.21 Under

17. Epidemiological studies of groups of humans who have historically received greater than normal exposures to chemicals can provide some direct evidence of risk, but these studies are notorously inconclusive. See Cranor, Epidemiology and Procedural Protections for Workplace Health in The Aftermath of the Benzene Case, 5 INDUS. REL. L.J. 372, 382-96 (1983) (practical and theoretical difficulties with epidemiological studies of human beings create problems of accuracy and reliability); Latin, The "Significance" of Toxic Health Risks: An Essay on Legal Decisionmaking Under Uncertainty, 10 ECOLOGY L.Q. 339, 361-64 (1982) (deficiencies in epidemiological data on benzene could not be remedied, and hence were characterized as "knowledge uncertainty"); McGarity, Substantive and Procedural Discretion in Administrative Resolution of Science Policy Questions: Regulating Carcinogens in EPA and OSHA, 67 GEO. L.J. 729, 740 (1979) (epidemiological studies are subject to varying interpretatious). Moreover, the validity of virtually any animal study can be significantly challenged by such questions as the appropriateness of extrapolating from high-dose animal exposures to low-dose human exposures, the choice of the particular species, the validity of test designs, and the applicability of exposure routes. See R. MERRILL, FEDERAL Regulation of CANCERCausing Chemicals 58-71 (1982) (report for ACUS); Office of Science and Technology Policy (OSTP), Chemical Carcinogens; A Review of the Science and its Associated Principles, February, 1985, 50 Fed. Reg. 10,372, 10,420-21 (1985). In addition, few studies can satisfactorily surmount the problems inherent in calculating the number of persons exposed to any chemical. This information is expensive to obtain, and OSHA must heavily rely upon employers for this critical piece of the puzzle. See McGarity, Media-Quality, Technology, and Cost-Benefit Balancing Strategies for Health and Environmental Regulation, LAW \& CONTEMP. PROBS., Summer 1983, at 159, 183-85 [hereinafter McGarity, Media-Quality]; Merrill, supra, at 74-82; OSTP, supra, at 10,424.

18. See Cranor, supra note 17, at 381; Latin, supra note 17, at 370-71; Comment, The Significant Risk Requirement in OSHA Regulation of Carcinogens: Industrial Union Department, AFL. CIO v. American Petroleum Institute, 33 STAN. L. REv. 551, 565 (1981).

19. See Cothern, Coniglio \& Marcus, Estimating Risk to Human Health, 20 ENVTL. ScI. \& TECH. 111, 115 (1986).

20. See J. MENDELOFF, supra note 9, at 248.

21. To support his estimate, Mendeloff cites a study that relied on an early epidemiological study of workers exposed to vinyl chloride. This study estimated that only two deaths would be prevented each year by the current vinyl chloride standard. J. MENDELOFF, supra notc 9, at 66 . However, the study depends on the astounding assumption that the 21 angiosarcoma deaths definitively attributed to vinyl chloride exposure through 1976 constituted all of the deaths caused by vinyl chloride during the preceding forty years. Mendeloff also interprets an Environmental Protection Agency (EPA) risk assessment based upon animal bioassays to conclude that only two cancers per year would be prevented by the standard. But to reach this result, he reduced EPA's predictions by a factor of eight to take into account the fact that workers are only exposed for eight hours per 
this alternative calculation, the vinyl chloride standard costs only $\$ 1$ to $\$ 2$ million per life saved, which is well within the cost range that most persons, includimg Mendeloff, ${ }^{22}$ would consider reasonable. ${ }^{23}$

In addition, Mendeloff fails to factor many benefits of health and safety regulation, other than the saving of lives, imto his cost-benefit calculus. For example, Mendeloff does not attempt to measure the value of reducing the number of non-fatal illnesses, the lost productivity attributable to occupational disease, or the welfare and social security payments made to workers who become ill. ${ }^{24}$ Mendeloff also fails to consider adequately other "soft variables" benefits, such as the emotional loss to the injured workers' loved ones. Mendeloff argues that the "willingness to pay" measurement of benefits imcludes these benefits because workers factor the potential cost of the consequences of occupational illness into the payment they demand. ${ }^{25}$ No empirical evidence yet supports this claim. Moreover, the suggestion that people accurately consider the possible future loss of productivity when they engage in risky conduct, let alone the loss of grieving relatives, seems on its face highly implausible. ${ }^{26}$

The vagaries inherent in calculating the benefits of a health or safety standard extend beyond the uncertamties in estimating the number of lives saved, the number of illnesses prevented, and the amount of pain

day for 45 years. Id. at $288 \mathrm{n} .21$. Yet given that the EPA risk assessment could easily be off by a factor of ten, that estimate might just as easily be 20 or even 40 cancers per year.

22. In his benefit calculations, Mendeloff values each life at $\$ 2.5$ million. J. MENDELoff, supra note 9 , at 52 .

23. Sunstein or Mendeloff might respond that the imprecision in risk assessments does not justify choosing the upper confidence level to calculate the benefits of a standard. However, estimating higher risk levels than those indicated by the use of the lowest confidence level is valid if the purpose of the regulatory scheme is to increase the protection of workers from toxic substances, rather than to minimize worker protection. On a narrower ground, Mendeloff can sustain his argument that the vinyl chloride standard is an egregious example of overregulation only by using the lowest estimate of risk to calculate the benefits of the standard. Because it is equally plausible that the number of lives saved is greater than Mendeloff's estimates, we are reluctant to base public policy on calculations that are so imprecise.

24. Savings associated with reducing welfare and social security payments may be considerable. In fiscal year 1989, social security payments to disabled workers (for injuries and illnesses) totaled $\$ 7.65$ billion. National Safe Workplace InSTITUTE, Safer Work: Job SafeTy and Health Challenges for the Next President and Congress 7 (1988).

25. See J. MENDELOFF, supra note 9, at 27.

26. In effect, Mendeloff simply ignores these important consequences of occupational illness, rather than attempting to measure them or place a dollar value on them. This blindered view is typical of the economist's tendency to "dwarf soft variables" that do not lend themselves to precise quantitative analysis. See Tribe, Ways Not to Think About Plastic Trees: New Foundations for Environmental Law, 83 YALE L.J. 1315, 1318-19 (1974) (being under constant pressure to reduce the dimensions of a problem to "hard" data so as to make "objective" comparison possible, some policy analysts are induced to "overlook or understress a variety of values that might, in context, be characterized as 'fragile" "). 
avoided. The dollar-for-dollar comparisons that both Mendeloff and Sunstein advocate require that the numerical estimates of risk be multiphed by the dollar value of avoiding each of those unattractive outcomes. ${ }^{27}$ Thus, Mendeloff calculates the value of a human bife as $\$ 2.5$ million, relying on a "willingness to pay" measurement defined by the wage that premium workers receive for working in dangerous conditions. ${ }^{28}$ However, most wage premium studies (and all of those used by Mendeloff) are based on safety hazards, not health risks. ${ }^{29}$

The hittle enpirical evidence available on wage premiums for occupational illness is suspect for three reasons. First, most studies pre-date the miplementation of OSHA's hazard communication standard. ${ }^{30}$ Even with the hazard commuincation standard, many workers are still not apprized of all of the health risks to which they are exposed. ${ }^{31}$ Second, even assuming the availability of full information, most workers would be unable to wade through the extraordimarily complex risk data to form rational conclusions about the extent of risks in the workplace. ${ }^{32}$ Even if workers could understand the data, they would likely undervalue lowprobability/high consequence risks based on the familiar "it-can't-happen-to-me" theory. ${ }^{33}$ In this case, "risk premium" measures of small risks to life would generally be too low. ${ }^{34}$ Finally, wage premium studies assume that workers make free and unconstrained choices. Unfortunately, low-paid workers in hazardous industries where there are no (or weak) umions may act more out of desperation than choice. ${ }^{35}$

\section{See J. Mendeloff, supra note 9, at 27.}

28. Id. at 29.

29. See id. at 44-45. Mendeloff hypothesizes that workers would pay less for reductions in health risks than safety risks because illnesses, as compared to accidents, occur later in life. But even Mendeloff concedes that workers might pay more to reduce health risks because cancer is a painful and dreaded disease. $I d$. at 48.

30. For example, only five of the eighteen wage-premium studies cited by Mendeloff, see $\mathrm{J}$. MENDELOFF, supra note 9, at 28, post-date OSHA's original hazard communication standard, which was promulgated in 1983. See 48 Fed. Reg. 53,280 (1983).

31. See Settle \& Weisbrod, Governmentally-Imposed Standards: Some Normative Aspects, Institute for Research on Poverty, Discussion Paper No. 439-77, at 27-28 (University of WisconsinMadison, 1977).

32. See id.

33. See id. at $28,31$.

34. See P. Asch, Consumer Safety Regulation: Putting a Price on Life and Limb 70-77 (1988).

35. See A. Okun, Equality and Efficiency: The Big Tradeoff 21 (1975); Kelinan, CostBenefit Analysis and Environmental, Safety, and Health Regulation: Ethical and Philosophical Considerations, in Cost-Beneftr Analysis and Environmental Regulations: Politics, Ethics, AND METHODS 137, 144 (D. Swartzman, R. Liroff \& K. Croke eds. 1982). Walking away from a job is a difficult choice in an era of chronically high unemployment. The dissatisfied worker who quits often loses personal and family pension benefits and health insurance in addition to losing his or her stream of income. The worker may also have to undergo retraining and incur other transaction 
In addition, basing calculations of benefits on supposed wage premiums entails two controversial value judgments. First, most economists (although not Mendeloff) beheve in discounting future health benefits to present value. Yet in cases of toxic substance exposure, where the onset of disease can be delayed by as much as thirty years, this practice effectively ignores the risk altogether. ${ }^{36}$

Second, most of those who advocate application of lealth, safety, and environmental regulation to a quantitative cost-benefit litmus test apparently prefer a "willingness to pay" measure of the benefits of a lealth or environmental regulation to a "willingness to sell" approach. ${ }^{37}$ Unlike many economists, Sunstein understands the "offer-asking" problem and recognizes the "willingness to sell" approach as the better measure, because it is not limited by the wealtll of the beneficiaries of regulation. ${ }^{38}$ Yet Sunstein fails to acknowledge the implications that this critical choice lias on Mendeloff's conclusions. Sunstein accepts the conventional economic wisdom that health and environmental regulations liave "inposed enormously high costs for speculative benefits." 39 By this, he presumably means that the costs of these standards are so high that no conceivable "willingness to buy" valuation would justify thein. However, Sunstein avoids the mucl liarder question of whether the more equitable "willingness to sell" measure might actually.justify health and environinental regnlation. Instead, he inerely assumes that Mendeloff's questionable methods of calculation are the proper measure of these regulations' costs and benefits.

Given the vast technical uncertainties and anchorless moral judgments reflected in the cost-benefit calculations for health and safety standards, basing important public pohicy decisions on these quantitative

costs. See Schroeder \& Shapiro, Responses To Occupational Disease: The Role of Markets, Regulation, and Information, 72 GEO. L.J. 123.1, 1241 (1984).

36. See Russell, "Discounting Human Life" (Or, the Anatomy of a Moral-Economic Issue), RESOURCES, Winter 1986, at 8 . However, economists are untroubled by the practice, arguing without empirical evidence that people probably place a lower value on reducing risks that materialize in the future. See, e.g., J. MENDELofF, supra note 9, at 49.

37. See, eg., M. GREEN \& N. WAITZMAN, supra note 16, at 43-48.

38. See Sunstein, supra note 1, at 634. There is no reason to believe that a poor person would sell the right to be safe for any less than a rich person would. There is every reason to believe, however, that a person's wealth will affect how much he or she can pay to purchase the right to be safe. Indeed, economic research cited by Mendeloff indicates as much. A study by Marin and Psacharopoulos using the willingness to pay criteria found that the best estimate of the value of life was \$2.5 million for manual workers and \$9.0 million for non-manual workers. J. MENDELOFF, supra note 9, at 28, Table 2.3 (citing Marin \& Psacharopoulos, The Reward for Risk in the Labor Market: Evidence from the United Kingdom and a Reconciliation with Other Studies, 90 J. PoL. ECON. 827 (1982)). Presumably, the estimate for a class limited to company presidents and board chairpersons would be even higher.

39. Sunstein, supra note 1 , at 625 . 
cost-benefit comparisons is patently unreasonable. Although Sunstein avows that he is doing nothing of the kind, and specifically cautions that cost-benefit analysis is only an effort "to compare the advantages and disadvantages of regulatory strategy," 40 his policy conclusions display little of this laudable restraint. Relying uncritically on Mendeloff's poorly supported conclusion that OSHA's existing health standards result in overregulation, Sunstein is fully prepared to abandon technology-based regulation and to advocate that courts should presume that Congress wants agencies to balance costs and benefits when they proinulgate regulations. ${ }^{41}$

\section{B. The Consequences of Strict Regulation}

Even assuming that OSHA has engaged in "overregulation," as Mendeloff defines the term, it does not necessarily follow that underregulation has resulted. Sunstein argues, relying again on Professor Mendeloff, that overregulation leads to underregulation because the "threat of dracomian regulatory requireinents gives industries powerful incentives to fight regulation wherever they can, and gives agencies a powerful incentive not to proinulgate or enforce then." 42 OSHA's actual experience in setting standards, however, demonstrates the naive behef that less strimgent standards will reduce industry opposition.

For exainple, the standard that Sunstein identifies as the most "reasonable" of all OSHA's early standards-the asbestos standard-was fiercely challenged by industry, ${ }^{43}$ even though the adverse effects of asbestos on workers were incontrovertible. ${ }^{44}$ In addition, the industry fought OSHA's attempts to amend the 1972 asbestos standard for over a decade, even though Mendeloff himself concedes that cost-benefit calculations warrant even further reductions in asbestos exposure. ${ }^{45}$ The sug-

40. Id. at $626 \mathrm{n} .83$.

41. See id. at 626-27.

42. Id. at 630.

43. See Industrial Union Dep't v. Hodgson, 499 F.2d 467,479 (D.C. Cir. 1974) (industry representatives testified that they could not foreseeably reduce asbestos dust concentrations to the twofiber standard promulgated by OSHA).

44. See id. at 471 \& n.7; Mintz, Occupational Safety and Health: The Federal Regulatory Program-A History, in Fundamentals of INDUSTRIAL HygIENE 691, 695-96 (B. Plog ed. 1988) (description of asbestos standard challenge).

45. See J. Mendeloff, supra note 9 , at 22, 52. The industry reduced its opposition to the OSHA asbestos standard only when the EPA decided to ban the substance under the Toxic Substances Control Act, 15 U.S.C. $\$ 2605$ (1988). See Asbestos Manufacturing, Import, Processing Banned, Phased out under Final EPA Regualations, 20 Env't Rep. (BNA) 534 (July 14, 1989) (reporting EPA Administrator William Reilly's press conference announcement of the ban). At that point, industry pressured the Office of Management and Budget (OMB) to force the EPA to refer the standard to OSHA. See SUBCOMM. ON TOXIC SUBSTANCES AND ENVIRONMENTAL OVERSIGHT OF the Senate Comm. on the Environment and Public Works, 99th Cong., 2D Sess., Office 
gestion that industry will be persuaded not to challenge a standard that inposes substantial costs on its members merely by the fact that the benefits to someone else will be even larger than the costs to the industry is clearly fanciful.

Moreover, the fate of OSHA's new air contaminants standard ${ }^{46}$ provides an even clearer contradiction of the Sunstein-Mendeloff thesis that strict regulation spurs mdustry opposition and agency inaction. In the new regulation, OSHA adopted less stringent standards for air contaminants by relymg almost exclusively on threshold limit values (TLVs) established by the American Conference of Governmental and Industrial Hygiemists (ACGIH), rather than promulgating feasibility-based standards for each of the more than 400 substances for which permissible exposure limits (PELs) already existed. ${ }^{47}$ This approach cannot be characterized as unduly stringent, even by Mendeloff's own cost-benefit test; he predicts that these moves to relax regulatory requirements will overcome the overregulation/underregulation problem. ${ }^{48}$

However, the new standard was challenged by twenty-eight different companies and trade associations. ${ }^{49}$ OSHA attempted to settle the cases by compromising with the challengers. Most of the proposed concessions were inade by OSHA and involved reductions in the stringency of the new PELs. Despite OSHA's willingness to make significant concessions to avoid litigation, eleven challengers insisted on going to court. ${ }^{\text {so }}$

The fact that so many compamies and trade associations were willing to undergo the substantial expense of a judicial challenge is understandable, given the economics of the situation. OSHA estimated that the average annual cost of complying with each of the 376 PELs in the air contaminants standard was about $\$ 2$ million. ${ }^{51}$ Because judicial review "delay[s] the implementation of OSHA standards by an average of two years," $\$ 2$ a company or trade association could save its industry $\$ 320,000$

of Management and Budget Influence on Agency Regulations (Comm. Print 1986). Even then, the industry did not stop resisting a stringent standard. The amended standard that OSHA finally promulgated was remanded by the Court of Appeals for the District of Columbia Circuit, because OSHA failed to adequately address union objections. See Industrial Union Dep't, AFL-CIO v. Hodgson, 499 F.2d 467 (D.C. Cir. 1974).

46. Amendment of Air Contaminants Standard, 54 Fed. Reg. 2332 (1989) (codified at 29

C.F.R. $\S 1910.1000$ ).

47. Id. at 2724-25.

48. See J. MENDELOFF, supra note 9, at 85-87.

49. See Challenges to Air Contaminants Standard Filed in Circuit Courts, Einpl. Safety \& Health Guide (CCH) No. 935, at 1 (Apr. 11, 1989).

50. Telephone interview with Charles Gordon, Office of the Solicitor, Department of Labor (May 22, 1990).

51. 54 Fed. Reg. at 2851-53.

52. Schroeder \& Shapiro, supra note 35 , at 1257-58. 
by filing an appeal, assuming an eight percent annual interest rate. Therefore, even if the trade association discounted the prospects of victory, it could justify an appeal to its members as long as the appeal cost less than $\$ 320,000$. If the association's lawyers spent 500 hours on the appeal (which seems more than sufficient to appeal even a complicated standard), the association could afford legal fees of up to $\$ 640$ an hour and still save its members money compared to the costs of immediate comphance with the OSHA standard. Investment im an appeal becomes more attractive when the trade association can purchase legal services at less than $\$ 640$ an hour (a likely possibility), when the industry can place the money saved into imvestments that yield a higher return than eight percent, or when the standard is likely to cost the industry more than $\$ 2$ million.

Although most affected industries did not challenge the air contaminants standard, the reason is simple: in eighty percent of the cases, the standard merely adopted the status quo. ${ }^{53}$ Concededly, the standard does provide additional protection to approximately four and one-half million workers, ${ }^{54}$ but the level of protection is very limited. A recent study found that "[t]he Air Contaminants standard is more conservative than the ACGIH im the treatment of occupational carcinogens." 55 The ACGIH generally will not characterize a substance as a carcmogen unless there is epidemiological data indicating that it has caused cancer in humans. ${ }^{56}$ Health-oriented federal agencies, with the exception of OSHA in promulgating this air contaminants standard, abandoned this conservative strategy decades ago as a "body-counting" approach to standard setting. Moreover, the ACGIH ignores published scientific material and rehes more heavily on mdustry-supphied data than OSHA generally does in its promulgation of health standards. ${ }^{57}$

53. 54 Fed. Reg. at 2727 (OSHA survey indicated that only 131,005 firms of 500,000 included in survey would incur costs to comply with new standard).

54. Id. at 2725.

55. Paxman \& Robinson, Regulation of Occupational Carcinogens under OSHA's Air Contaminants Standard, 12 Regulatory Toxicology \& Pharmacology 296, 302 (1990).

56. See J. MENDELOFF, supra note 9, at 292 n.26.

57. See Castleman \& Ziem, Corporate Influence On Threshold Limit Values, 13 AM. J. INDus. MED. 531, 537 (1988) (many TLVs approved by ACG1H committees based on little or nothing more than unpublished corporate cominunications and studies); Roach \& Rappaport, But They Are Not Thresholds: A Critical Analysis of The Documentation of Threshold Limit Values, 17 AM. J. INDUS. MED. 727, 733 (1990) (marked discordance between TLV and scientific evidence considered by ACGIH). OSHA defends its reliance on TLVs on the ground that they often constitute the only reliable basis for a generic standard, see Amendınent of Air Contaminants Standard, 54 Fed. Reg. 2727 (1989) (codified at 29 C.F.R. $\$ 1910.1000$ ), but this argunnent has been forcefully rebutted. See Robinson, Paxman \& Rappaport, Implications of OSHA's Reliance on TLV's in Developing the Air Contaminants Standard, 19 AM. J. INDUS. MED. 3, 10-12 (1991) (arguing that the TLV process is 
This experience suggests that industry will generally resist any new OSHA regulation as long as companies find it economically beneficial to invest resources in hitigation over investments in safety. How cost-beneficial OSHA's standards appear to disinterested economists is irrelevant to the industry.

Ultimately, the argument that "overregulation causes underregulation" fails because of its one-sided view of the problem of industry opposition. We therefore urge that instead of concentrating on overregulation (as do Sunstein and Mendeloff) and im effect yielding to industry extortion, Congress should focus on the underregulation side-by inaking it easier for OSHA to regulate. This could be done by reducing the burden of proof that OSHA inust present to defend strict standards. ${ }^{58}$

Although Sunstein, unlike Mendeloff, is willing to acknowledge that cost-benefit analysis is not always the most appropriate basis for regulation, neither Sunstein nor Mendeloff can adequately explain why we should not solve the problem of underregulation by reducing the governinent's burden of proof, rather than by reducing the level of protection afforded to the intended beneficiaries.

\section{The Normative Basis For Technology-Based REgULATION}

The choice of any regulatory approach can be debated on normative and instrumental grounds. In this section, we argue that normative considerations inake technology-based approaches preferable to cost-benefit approaches. In the following section, we address the instrumental concerns involved in determining the relative effectiveness of Sunstein's proposed reforms and technology-based approaches.

Economists defend the use of cost-benefit standards in formulating social policy on risk reduction by arguing that, in some cases, it is less expensive for society when employers pay coinpensation for illnesses

highly unreliable because of dependence on industry and discrepancies between TLV decisions and literature cited by TLV coinmittees).

58. We have elsewhere suggested several ways in which OSHA's standard-setting burdens can be reduced. See Shapiro \& McGarity, Reorienting OSHA: Regulatory Alternatives and Legislative Reform, 6 YALE J. ON REG. 1, 47-49 (1989). Mendeloff himself concludes that the fundamental cause of delay in OSHA standard-setting is the fact that OSHA bears the burden of denonstrating the necessity of any change in the status quo. See J. MENDELOFF, supra note 9, at 137-38. This strongly suggests that the solution to the problem of underregulation lies in finding ways to rehieve OSHA of this burden. Mendeloff argues that "[t]he fundamental reform that would clear the way for a faster pace of standard setting is a lower standard of proof, construed broadly to include the reviews of all the influential outsiders, not just the courts." Id. at 138. However, Mendeloff is unwilling to reduce OSHA's burden unless the standards pass the cost-benefit test he advocates. "It would be a inistake to lower the burden of proof in the regulatory standard-setting process without also establishing some mechanism to encourage balancing." Id. at 240. 
rather than spending money to prevent them. This argument, however, ignores the ethical distinction between preventing death and compensating the victim's family after death occurs. As the Supreme Court's Cotton Dust ${ }^{59}$ reading of the OSHA Act's legislative history indicates, Congress apparently had this im mind when it rejected cost-benefit analysis for OSHA health standards. ${ }^{60}$ In addition, placing the entire burden of less stringent cost-benefit-based standards on workers is inequitable. Even if milder standards would ultimately make more resources available to society, there is no reason why workers should not be fully compensated for the losses they sustain that could have been prevented under more stringent standards. In other words, the resources saved by a switch to less stringent standards should go to the injured workers, rather than to the employers or their customers. Yet few economists advocate redistributing the efficiency gains of cost-benefit approaches to workers. ${ }^{61}$

Indeed, economic analysts respond that the distributional consequences of their prescriptions are beyond their bailiwick. For example, Mendeloff recognizes that the winners of a policy prescription do not necessarily have to pay the losers for their losses under his cost-benefit approach:

Those who die because society rejects inefficient lifesaving programs will not be around to benefit from the bigger pie. Does this fact require condemnation of any policy that stops short of a maximum effort to prevent deaths? No. It is inevitable that public policy will create losers who are beyond the reach of compensation. But this fact should spur thimking about who the losers are and how we feel about their plight. ${ }^{62}$

Surviving family members of workers whose deaths could have been prevented at a cost somewhat greater than the economist's optinal expenditure will take no comfort im the assurance that the loss of their loved one will stimulate scholars to think more about how society should feel about their plight.

59. American Textile Mfrs. Inst. v. Donovan, 452 U.S. 490 (1981).

60. Id. at $519-20$.

61. Some economists do agree that the saved resources should go to the workers, but they argue that workers are already compensated for unprevented illnesses ex ante through wage premiums or ex post through workers compensation. See W. Viscusi, Risk By Chorce: Regulating Health AND SAFETY IN THE WORKPLACE 37-58, 84 (1983). If, however, workers are not compensated for risk, these economists argue that they should be. See id. at 60 . But many workers (or their families) are not adequately compensated for unprevented illnesses. See Schroeder \& Shapiro, supra note 35, at 1244-50; infra note 116 and accompanying text. Moreover, reforms that guarantee full compensation are extremely unlikely. See infra note 115 and accompanying text.

62. J. Mendeloff, supra note 9 , at 33. 
When the distributional consequences of a cost-benefit regulatory world are considered, it becomes obvious that cost-benefit approaches undercompensate workers in two ways. First, cost-benefit analysts underestimate the value of a life. ${ }^{63}$ Second, compensation systems pay workers less than the full value of their lives, as defined by economists. ${ }^{64}$ Indeed, some workers are not compensated at all. Althougl1 public policy may inevitably create some losers beyond the reacli of compensation, the cost-benefit approach creates too many uncompensated losers when compared with technology-based approaches.

In a world where workers are seldom fully compensated for occupational illness, the merit of a technology-based approach is that it reduces the need for victims to resort to the compensation system to a much larger degree than does the cost-benefit approach. Under the cost-benefit approach, significant financial burdens fall on those who are least able to sustain them, i.e., workers and their families. In comparison, the additional costs imposed by technology-based standards are passed on to consumers or absorbed by stockholders. The individual impact of these costs on any one consumer or stockholder is insignificant compared to the burden imposed on umcompensated or undercompensated workers and their families, who are forced to absorb the entire cost of their illnesses. Protecting workers with teclinology-based standards may be more costly to society than compensating them after-tle-fact. But in the absence of a realistic mechainism to ensure adequate compensation, fairness demands that workers be protected from incurring the costs of illness where possible. ${ }^{65}$

Mendeloff and other economic critics have difficulty believing that Congress really rejected the use of cost-benefit analysis. ${ }^{66}$ Because no rational consuiner would pay $\$ 25$ in a private market for something that is worth only $\$ 20$, the economist assumes that voters also intend for their representatives to reject policies whose costs exceed their "economic" benefits.

However, the economist fails to understand that public, social decisions provide citizens witl an opportunity to give certain things a higher valuation than they would otherwise choose to give thein in their private activities or in their capacity as individuals. In public forums, individu-

63. See supra notes $27-29$ and accompanying text.

64. See infra note 115 and accompanying text.

65. Sunstein objects to using regulation for redistributional purposes on the instrumental grounds that this method is inefficient and calls for increased use of workers compensation. See Sunstein, supra note 1 , at 640 . If cost-benefit approaches fully compensated workers for their injuries, these objections would no longer be valid. But, as discussed later, it is unlikely that this will happen even under Sunstein's proposed reforms. See infra note 115 and accompanying text.

66. See J. MENDELOFF, supra note 9, at 15. 
als are often willing to vote for outcomes that economic analysis would characterize as inefficient because these outcomes can confirm and serve important noneconomic values. ${ }^{67}$ As consumers, we may dislike paymg more for manufactured products because of the costs of protecting workers, but as citizens we can rationally vote for these types of costly and (by the econoimst's "willingness to pay" ineasure) irrational goals. We vote in favor of such costly goals because they permit us to reaffirm our ideal that preventable occupational diseases are not merely inefficient-they are wrong. ${ }^{68}$

Sunstein's analysis on this point is distressingly ambiguous. On one hand, Sunstein acknowledges the normative legitimacy of usmg the politieal system to implement values that do not receive adequate recognition in inarkets, ${ }^{69}$ and he eloquently opmes that "[s]onetimes the strongest arguments for regnlation sound in deinocracy rather than efficiency."70 In particular, Sunstein cites the protection of the environment and of endangered species as important examples of the impleinentation of democratic aspirations, or noncommodity values, that the inarketplace undervalues. ${ }^{71}$ Yet in virtually the same breath, Sunstein recoinmends that pohicy-makers, as well as courts, hew to a proportionality primciple in setting regulatory goals, ${ }^{72}$ and "adopt a strong presuinption in favor of flexible, market-oriented, incentive-based regulatory strategies" at the implementation stage. ${ }^{73}$

One is tempted to conclude that Professor Sunstein wants it both ways-a inarket-oriented world in which noncommodity values hold sway. However, leveling charges of hypocrisy at Professor Sunstem may be unfair. He inay inerely be trymg to find some middle ground to which both ends of the political spectrum can gravitate: Sunstein may be arguing that although it is appropriate for Congress to require strict regulation on behalf of noncommodity values, policymakers and the courts

67. See Frank, $A$ Theory of Moral Sentiments, in BEYOND SELF-INTEREST 71-72 (J. Mansbridge ed. 1990).

68. In other words, "[t]he goals that we set as voters constantly remind us as we assume our role as consumers that there are things in life more important than the pursuit of material wealth." McGarity, Media-Quality, supra note 17, at 194-95.

69. See C. Sunstein, AfTer the Rights Revolution 57-58 (1990).

70. Sunstein, supra note 1 , at 620 . The most persuasive proponent of this viewpoint is Professor Sagoff, whose numerous works Sunstein fails to mention. See, e.g., M. SAGOFF, THE ECONOMY OF THE EARTH (1988).

71. See C. SUNSTEIN, supra note 69 , at 183.

72. See C. SUNSTEIN, supra note 69 , at 182 (discussing with approval National Resources Defense Council, Inc. v. Thomas, 805 F.2d 410 (D.C. Cir. 1986), which concluded that a section of the Clean Air Act was subject to a cost-benefit standard although Congress had made no reference to one).

73. Sunstein, supra note 1, at 633 . 
shbuld not assume that it has done so unless Congress has clearly announced such an intention. Convinced that "strict government controls ... produce underregulation as well as overregulation," 74 Sunstein may conclude that a presumption in favor of market values will best serve the interests of workers and environmentalists. If so, the labor and environmental groups that Sunstein seeks to help remain singularly unconviniced. These groups have consistently opposed cost-benefit balancing as a test for setting regulatory goals, ${ }^{75}$ and, with a few exceptions, they have resisted incentive-based implementation techniques. ${ }^{76}$

Alternatively, Sunstein may be saying than he favors strict regulation, but not to the point where we spend huge anounts of money to obtain speculative benefits. Thus, although Sunstein may not require costs and benefits to be exactly equated, he inght oppose strict regulation if the ratio of costs to benefits gets too far out of line. In this case, Sunstein's arguinent merely sounds a sensible cautionary note that in the context of regulation, pushing too hard inay be counterproductive. ${ }^{77}$

If Sunstein in fact finds himself closer to this latter position, we would urge him to reconsider his opposition to the teclnology-based approach. Teclnology-based regulation is concededly imperfect. It spawns messy legislative and judicial struggles, is subject to industry and agency manipulation, and often appears irrational when measured by comprehensive analytical rationality standards. ${ }^{78}$ But this "academic failure" has been an enormous success in the real world. ${ }^{79}$

In addition to the proven effectiveness of the technology-based approaches, technological requirements reflect a considered normative choice about the proper balance between lives and monetary costs. Acknowledging that society cannot vest workers with an unqualified right

74. Id. at 630 .

75. See, e.g., Claybrook \& Bollier, The Hidden Benefits of Regulation: Disclosing the Auto Safety Payoff, 3 YALE J. ON REG. 87, 125-131 (1985) (describing the opposition to cost-benefit analysis by the president of Public Citizen). See generally S. Hays, Beauty, HealTh, AND PermaNence: ENVIRonmental Polmics IN THE United States 1955-1985, at 391 (1987) (environmental advocacy of general public divorced from use of economics as a policy tool).

76. See, e.g., Breger, Stewart, Elliott \& Hawkins, Providing, Economic Incentives in Environmental Regulation, 8 Y ALE J. ON REG. 463, 481-82 (1991) (remarks of David Hawkins, a member of the Natural Resources Defense Council).

77. Altlough we find this interpretation of Sunstein's position very attractive, it raises the troubling question of low mucl expense on risk reduction teclinology is "too inuclı." We lave no bright-line answer to this question. The familiar notion of the "knee-of-the-curve" (the point on the cost curve where costs begin to escalate dramatically) may provide an attractive starting point. However, we suspect that uncertainties in the data often lide that elusive cost-curve crook. See McGarity, Media-Quality, supra note 17, at 183.

78. See T. McGarity, Reinventing Rationality: The Role of Regulatory Analysis IN THE Federal Bureaucracy $211-20$ (1991).

79. See infra note 93 and aceompanying text. 
to an absolutely safe workplace, one may rationally assert that workers do have a right to insist that employers "do the best they can" to protect human health. In other words, society might justifiably decide to reduce risky behavior beyond the point indicated by a cost-benefit test. Indeed, society may choose to limit its protection of workers only at the point where the protection would cause industry substantial economic dislocation. ${ }^{80}$ This pomt seens to elude Sunstein altogether. ${ }^{81}$ Moreover, Sunstein's own approach lacks any moral coinpass for determining what level of risk is appropriate in hard cases. Although Sunstein is prepared to abandon BAT for the use of financial incentives, he seens uncoinfortable with Mendeloff's advocacy of a strict quantitative cost-benefit test for the validity of regulations. ${ }^{82}$ In rejecting systems that solely rely on inarket tests, Sunstem abandons efficiency as the primary goal for regulation. Yet Sunstein does not offer any overriding substitute goal for regulation, because he also discards the BAT approach, which unabashedly makes worker protection its primary goal. ${ }^{83}$ Instead, Sunstein proposes a sensible-sounding, but ultmiately unsatisfying, "hite" version of cost-benefit analysis that offers no better guidance for inaking difficult line-drawing judgments than the technology-based approach.

\section{The Instrumental Basis For TechNology-BASED REGULATION}

In addition to advocating a "hte" cost-benefit test for regulatory goals, Sunstein beheves that market-oriented impleinentation techniques will more appropriately achieve regulatory goals. ${ }^{84}$ Sunstein would erect a presumption in favor of market-based regulatory options, such as emissions trading and pollution taxes. ${ }^{85}$ These strategies, according to Sunstein, "will increase efficiency, promote [regulation's] own purposes, and-by focusing public attention on the right questions-further democratic goals as well." 86 Sunstem further clains that a switch from a

80. See Schroeder, In the Regulation of Manmade Carcinogens: If Feasibility Analysis is the Answer, What is the Question?, $88 \mathrm{MicH}$. L. REv. 1483, 1504 (1990). Although a BAT mandate could require employers to spend more money to protect workers than a cost-benefit mandate, in most cases BAT strategies do not threaten to put a substantial number of companies in economic jeopardy. Because BAT standards only require the adoption of technologies already in place in some firms in the industry, most industry members will be in a position to comply with the standards at a reasonable cost.

81. See Sunstein, supra note 1, at 629 (choice of BAT level is "largely ineidental" to the determination of the appropriate level of pollution).

82. See id.

83. See id. at 629-30.

84. See id. at 631-34.

85. See id. at 634-39.

86. Id. at 633. 
"command-and-control" technology-based approach to an incentivebased regime would solve many of the problems of OSHA's current regulatory program. ${ }^{87}$ Although we agree that a judicious use of marketoriented impleinentation techniques might well improve the current systein, we beheve that Professor Sunstein's enthusiasin is misplaced. More inportantly, in his attacks on the technology-based approach to regulation, Sunstein often mixes normative arguments about regulatory goals with instrumental arguments about reaching those goals. For example, Sunstein does not clearly recognize that incentive-based tools inay be used to reach the normative goal of installing the best available technology. ${ }^{88}$ Instead, Sunstein appears to view BAT and inarket-based approaches as mutually exclusive. In the process, Sunstein overstates both the ease of implementing his approach and the difficulty of inplementing technology-based commands.

Specifically, in discussing inarket-based incentives, Sunstein asserts that "[i]f the ultimate goal is to reduce pollution sharply, then we should simply issue few permits." 89 He also assumes that risks from toxic substances could easily be reduced by simply assessing high taxes on, for examples, toxic waste disposal and automobile ennissions. ${ }^{90}$ These optimistic assessments may underestimate the difficulties inherent in estiunating risks and benefits. In addition, the imcentive-based approach adds new uncertainties to the prediction of the number of permits and level of taxes necessary to achieve a given level of risk reduction, on top of the already existing uncertainties about how various levels of exposure to toxic substances affect humans and the environinent. Unless agencies are prepared to tolerate potentially high exposures and/or devastating shortterm economic consequences during the time it takes for the systen to reach "steady state," proceedings examining the level of tax or the issuable number of permits are likely to be highly contentious. Moreover, because industry will likely resist any change to the status quo, especially if it requires inmediate outlays, ${ }^{91}$ impleinentation of any market-based program is likely to be slow.

Sunstein cites the history of environmental legislation in support of his conclusion that an incentive-based approach could be inplemented

87. See id. at 640-41.

88. Indeed, the very first legislative proposal for a pollution tax in Congress (Senator Proxmire's sulfur dioxide tax of 1972) was aimed at providing sufficient economic incentives to induce power plants to install scrubbers. See J. Bonine \& T. MCGarity, The Law of ENVIRoNMENTAL PROTECTION 653-55 (1984).

89. Sunstein, supra note 1 , at 636 .

90. See id. at 637-39.

91. See Wolozin, The Economics of Air Pollution: Central Problems, LAw \& Contemp. PROBS., Spring 1968, at 227, 236. 
more easily than could the BAT approaches. ${ }^{92}$ In particular, he compares the productive results under the Clean Air Act (CAA) ${ }^{93}$ and the Clean Water Act (CWA) ${ }^{94}$ with the government's less effective attempts to regulate toxic substances. ${ }^{55}$ Ironically, the CAA and CWA both adopted technology-based approaches to a large extent.96 Moreover, when Congress recognized that the overwhelming uncertainties and analytical quagmires concerning risk assessment were bogging down the toxic substance programs, Congress first amended both statutes specifically to allow the EPA to implement technology-based approaches. ${ }^{97}$ Later, Congress moved to establish more stringent standards in cases where BAT failed to adequately protect the public lealth. ${ }^{98}$ Thus, Congress recognized, as Sunstem does not, that "the practical consequence of

92. See Sunstein, supra note 1 , at 627-28.

93. Air Pollution Prevention and Control Act, 42 U.S.C. $\$ \$ 7401-7642$ (1988).

94. Federal Water Pollution Prevention and Control Act, 33 U.S.C. $\S \S 1251-1376$ (1988).

95. See Sunstein, supra note 1 , at 625 .

96. The Federal Water Pollution Control Act Amendinents of 1972, Pub. L. No. 92-500, 86 Stat. 816 (codified at 33 U.S.C. $\$ \S 1251-1387$ (1988)), required direct industrial dischargers of conventional pollutants to install the "best practicable control technology" by 1977 and the "best available technology" by 1983. Id. § 301(b), 86 Stat. at 845 (codified at 33 U.S.C. $\S 1311(b)$ (1988)). The deadlines were extended in 1977, and the "best available technology" requirenent was changed to "best conventional technology" for normal water pollutants. See Clean Water Act of 1977, Pub. L. No. 95-217, $\S 42$, 91 Stat. 1566, 1582-83. The first round of controls resulted in some impressive reductions in conventional pollutant discharges. See Council on ENVIRONMENTAL QUALITY, ExECUTIVE OFFICE OF THE PRESIDENT, ENVIRONMENTAL TRENDS 31 (1989) (table showing effluent reductions associated with pulp and paper mills from 1973 to 1984). The results of the second round of controls are inore debatable, partially because its deadlines were extended in 1987, see Water Quality Act of 1987, Pub. L. No. 100-4, $\S 301,101$ Stat. 7, 29, and partially because of the agency's lack of enthusiasm for environmental goals during the critical implementation period of the early 1980s. See, e.g., Sen. Durenburger Pushes EPA to Set National Standards for Drinking Water, Daily Rep. Execs. (BNA) No. 56, at A-17 (Mar. 22, 1985); Toxic Waste Cleanup Sputters, Eng'g NewsRecord, Nov. 19, 1981, at 10.

The Clean Air Act adopted a technology-based approach for new sources of pollution. See 42 U.S.C. $\$ 7411$ (1988). The principal program aimed at requiring states to inplement plans to meet the media-quality-based ambient air quality standards identified in the Act for new and existing sources by the statutory deadlines. See id. $\S 7410$. Although states could adopt any credible impleinentation plan to mect the federal standards (including marketable permits and effluent fees) most states simply adopted technology-based regimes requiring major sources of pollution to install the best available technology. Perhaps incentive-based approaches would have achieved the same results more cheaply and quickly, but state environmental officials evidently thought otherwise.

97. Clean Water Act of 1977, Pub. L. No. 95-217, § 53(a)(2), 91 Stat. 1566, 1589.

98. EPA's first atternpt to regulate toxic water pollutants under section 307 of the Federal Water Pollution Control Act Amendments of 1972 becaine bogged down in a bout of seemingly interminable generic rulemaking. See Hall, The Control of Toxic Pollutants Under the Federal Water Pollution Control Act Amendments of 1972, 63 IowA L. REV. 609 (1978) (recounting origins of the consent decree that resulted from the bogged-down seetion 307 regulations). When the EPA's attempts to set standards for toxins under $\S 112$ of the Clean Air Act suffered a similar fate, Congress once again anended the Act, this time requiring that the EPA inandate "inaximum available control technology" for listed pollutants by statutory deadlines. Act of Nov. 15, 1990, Pub. L. No. 101-549, $\S 301,104$ Stat. 2531. 
making particularized risk estimates legally relevant ... is to emasculate the regulation of carcinogens under prevailing conditions of scientific certainty." 99

The recent amendments to the CAA that permit states to use emissions trading and pollution taxes do not refute this point. Congress has already estabhished the permissible levels of exposure for conventional pollutants in the CAA itself. ${ }^{100}$ Thus, financial incentives do not affect the decision of what ambient air quality standards are appropriate. Consequently, we do not oppose the added flexibility that the 1990 amendments give states to reach the predetermined goals. ${ }^{101}$

However, Congress has been slow to apply this lesson across the board. In fact, one of the reasons that OSHA has regulated so few toxic substances is that it is required to make individual risk assessments for each substance regulated. In the Benzene case, the Supreme Court read the risk assessment requirement into OSHA's legislative mandate ${ }^{102}$ although even Sunstein agrees that hittle in the text or history of the Act supports this interpretation. ${ }^{103}$ We have elsewhere proposed that Congress should give OSHA a choice between adopting less stringent BAT regulations and more strimgent regulations based on individual risk determinations. ${ }^{104}$ We are confident that this relatively modest change would speed up the decisionmaking process, just as the changes to the Clean Air Act and Clean Water Act did.

In addition to providing a speedier approach to regulation, BAT strategies, when compared to market-based approaches, stack up well on other instrumental grounds. A comparison of Sunstein's four indictments of BAT with the probable implementation difficulties of a marketbased approach indicates that BAT is not nearly as oafish as Sunstein suggests, and that market-based approaches are not nearly as neat.

In both cases, the installation of the required control technology may not be sufficient to protect public health to the desired degree. If so, further efforts, perhaps through some type of economic incentives, may be necessary. But a technology-based approach was necessary to get the programs off the ground.

99. Latin, Ideal Versus Real Regulatory Efficiency: Implementation of Uniform Standards and "Fine-Tuning" Regulatory Reforms, 37 STAN. L. REV. 1267, 1329 (1985).

100. See Clean Air Act Amendments of 1990, Pub. L. No. 101-549, §§ 101(b)-(d), 102(h), 107(c), 108(d), 412, 104 Stat. 2404, 2422, 2464, 2466, 2634.

101. However, we would caution that attempts to use economic incentives to regulate exposure to hundreds of toxic air pollutants in the absence of predetermined "acceptable" exposure limits would probably fail.

102. See Industrial Union Dep't, AFL-CIO v. American Petroleum Inst., 448 U.S. 607, 639-40 (1980) (the Benzene case) (plurality opinion).

103. See C. SunSTEIN, supra note 69 , at 194.

104. See Shapiro \& McGarity, supra note 58, at 45-50. 
First, Sunstein argues that because BAT strategies ignore the enorinous differences among plants in industries and among geographical areas, these strategies are "wildly inefficient."105 According to Sunstein, emissions trading programs perform inore efficiently because they allow firms with high abatement costs to buy additional permits to pollute from firms with low abatement costs. ${ }^{106}$ However, BAT systems do not operate in the blind manner that Sunstein indicates. No agency ignores the types of geographical and intra-industry differences Sunstein cites. Rather, agencies utilize a systein of variances to account for these differences. ${ }^{107}$ Emissions trading inay be less expensive to administer than the relatively cumbersome systein of variances, and the variance process can be abused to allow unjustified departures from the national standards. ${ }^{108}$ However, characterizing the BAT approach as "wildly" inefficient is an inaccurate overstatement of BAT's performance in practice.

Moreover, Sunstem fails to discuss the administrative costs associated with the reforms that he proposes. For example, because we do not know exactly how much abatement a pollution or injury tax would cause, the tax would likely have to be adjusted several times to meet the abatement goals. Aside froin the problem of whether Congress (or any legislature) would be willing to alter the tax after it has been initially set, the costs associated with these changes inust be factored into any comparison of BAT and market-related incentives.

Second, Sunstein argues that BAT strategies are "extremely expensive to enforce, imposing extraordinary inomitoring burdens" on EPA

105. See Sunstein, supra note 1, at 628.

106. See id. at 634 .

107. See Stewart, Economics, Environment, and the Limits of Legal Control, 9 HARv. ENvTL. L. REv. 1 (1985). From the very beginning, EPA has allowed any individual source that is subject to a "categorical" technology-based standard promulgated pursuant to section 301 of the Clean Water Act, 33 U.S.C. $\S 1311$ (1988), to demonstrate to the permitting official that it is entitled to a "fundamentally different factors" variance. The variance is available if the source demonstrates that factors relating to its waste stream are fundamentally different from the factors considered by EPA in establishing the standard. See Chemical Manufacturers Ass'n v. Natural Resources Defense Council, Inc., 470 U.S. 116 (1985) (fundamentally different factors variance available against standards for toxic substances); E.I. du Pont de Nemours \& Co. v. Train, 430 U.S. 112 (1976) (suggesting that a fundamentally different factors variance is required in the case of "best practicable technology" standards for conventional pollutants, but holding that such a variance is not required for new source performance standards).

108. Sources can attempt to obtain fundamentally different factors variances based on factors unrelated to the statutory criteria for defining categories of sources. For example, for a time sources sought fundamentally different factors variances on the ground that they were fundamentaly different in that they could not afford to install the required technologies. EPA's opposition to this attempt to abuse the variance process was upheld in EPA v. National Crushed Stone Ass'n, 449 U.S. 64 (1980). See also Georgia-Pacific Corp. v. EPA, 671 F.2d 1235, 1244 (9th Cir. 1981) ("[I]t is clear that the mere existence of 'different' factors at a particular site do not give rise to the 'fundamentally different factors' necessary to justify a variance."). 
and OSHA. ${ }^{109}$ But this is not reality. BAT strategies are less expensive to enforce because inspectors are only required to determine whether a firm has installed the required technology and continues to operate it properly. By comparison, emissions trading and pollution taxes require inspectors to monitor constantly the amount of pollution that a plant emits. In many cases, monitoring all the possible discharge points for air and water pollution will be far more expensive and difficult than identifying whether a firm is using a required technology. ${ }^{110}$ In the air pollution context, the incentive-based approach would create an incentive to abuse the systent by hiding emissions in all but the very simplest plants.

Third, Sunstein contends that because BAT strategies impose stricter regulatory requirements on new plants and industries than old ones, they penalize new products and thereby perpetuate old, dirty technology. ${ }^{111}$ In contrast, pollution taxes and marketable permits would, according to Sunstein, induce firms to invest in new technologies. ${ }^{112}$ To the extent the system is adequately pohiced to ensure that firms do not avoid paying the taxes in the first place, or cheat by emitting in excess of their permits, we agree with this assessment. However, the current income tax system, with its monuunent to the ingenuity of tax avoidance, does not inspire optimism on this point.

Finally, Sunstein objects to using regulation to pursue redistributive objectives, because it is less efficient in obtaining these objectives than more direct redistribution techniques. ${ }^{113}$ Thus, if society prefers to shift the costs of occupational disease from workers to their employers, Sunstein would advocate revamping workers compensation rather than using BAT strategies to accomplish this goal. ${ }^{114}$ Although we have already expressed normative objections to choosing compensation over prevention, we also believe that compensation is unlikely to be increased to the point where it fully compensates workers for their injuries and illnesses.

First, fifty states must act to reform workers compensation; this fact alone makes significant reform unlikely. In addition, experience indi-

109. See Sunstein, supra note 1 , at 628.

110. See McGarity, Media-Quality, supra note 17, at 210.

111. See Sunstein, supra note 1, at 628 . Sunstein also claims that BAT strategies target symptoms, rather than the underlying causes of pollution. Id. For example, Sunstein claims that the use of financial incentives to address the problem of acid rain, rather than the current "scrubbing technologies" requirements, will encourage American consumers and industry to shift from coal to cleaner, renewable fuels. See id. This argument, however, is just a variation of the argument that market-incentives are more likely to induce interest in new technologies or solutions to current problems.

112. See id. at 634-39.

113. See C. SUNSTE1N, supra note 69 , at 55-57.

114. See Sunstein, supra note 1, at 640 . 
cates that states are unlikely to increase benefits any time soon. ${ }^{115}$ In the face of employer threats to relocate to states less inclined to redistribute wealth from employers to employees, most states will be unwilling to become the first to reform their workers compensation laws. Congress could possibly overcome these difficulties by federalizing workers compensation, but it is unlikely to take such a drastic step in the near future because of political considerations. Congress might more feasibly enact an injury tax and make the proceeds available to the states to augment workers compensation funding for both imjuries and diseases. Although this could be a positive step drawing on the incentive-based approach and accomphishing redistributive goals, it would not address the more pressing problem of uncompensated workplace diseases.

Yet even this step is unlikely to provide full compensation for workers for injuries and illnesses. Workers compensation systems have been designed to keep an employee from starving, rather than to compensate the worker for medical expenses and lost wages. ${ }^{116}$ Thus, if Sunstein intends to ensure that workers compensation, an mjury tax, or some combination of the two forces employers to bear the full costs of the injuries and illnesses they cause, he should forthrightly press for the revolutionary recasting of current workers compensation regimes that this would require.

Even with its probleins, technology-based regulation compares favorably with market-related incentives from a strictly instrumental perspective. We therefore consider a more mcremental path to occupational safety and health reform more hikely. Congress might be persuaded to authorize OSHA to use BAT, while at the same time allow OSHA to

115. Although benefits levels have gradually improved in the last two decades, employers in most states have the political power to slow or stop most legislative reform efforts. See Schroeder \& Shapiro, supra note 35, at 1250 ("Opponents of reform represent an impressive political force. Typically, the insurance industry, workers compensation lawyers, and employers have combined to oppose reform efforts."). One expert points out that the increased cost of workers compensation insurance that accompanies increased benefits "make[s] further improvements in state laws more difficult and [has] generated pressures in several jurisdictions to reduce costs, often by cutting back benefits." Burton, Introduction, in NEW PERSPECTIVES IN WORKERS COMPENSATION 4 (J. Burton ed. 1988). He predicts that "in a number of states, there will be a continuing struggle to achieve or maintain adequate benefits, with the likely outcome that, in a significant minority, benefits will remain below the adequacy standards prescribed by the national commission." Id.

116. States have executed this policy by capping the amount of compensation an employer is required to pay at levels often far below einployees' salaries. For example, 42 states have a compensation cap of $\$ 450$ per week or less for employees who are temporarily unable to work. U.S. DEPARTMENT of Labor, OfFice of WORKERs CoMpensation Programs, State Workers' Compensation Laws Table 6 (1990). Alınost identical caps exist for permanent disabilities. Id. Table 7. Moreover, soine states do not even inect the goal of kecping employees from starving. In eight states, the inaximum compensation amount for teinporarily disabled workers is below the poverty level for a family of four. In another nine states, compensation is within $\$ 50$ of the poverty level. Id. Table 6. 
regulate more stringently if necessary to reduce or eliminate significant workplace risks. Unlike drastic workers compensation reform, this step would protect workers before they are injured, and reduce the number of illnesses for which employees would never be fully compensated because of difficulties in establishing cause-effect relationships between workplace exposures and individual diseases.

\section{CONCLUSION}

Sunstein's solution to the paradox he perceives-that "overregulation causes underregulation"-is to circumscribe toxic substance regulation by subjecting its regulatory goals to at least a weak form of costbenefit analysis. In addition, Sunstein advocates the use of measures like pollution taxes to dehiver more effective regulation. Although we agree that toxic substances are currently underregulated, our solution is precisely that which Sunstein condemns-a BAT approach to OSHA regulation as an initial step followed by more stringent regulation where necessary that could perhaps rely upon economic imcentives. Unlike Sunstein, we find no paradoxes in this approach. The evidence of overregulation marshalled by Mendeloff does not support his conclusions that OSHA's regulations entail costs that exceed benefits by millions of dollars or that stringent regulation causes underregulation. Industry will oppose both weak and strong regulations with equal vigor as long as it is in its financial interest to do so. Therefore, we behieve that the solution to industry opposition is to make it easier for OSHA to regulate, rather than yielding to industry opposition by abandoming the goals of occupational safety and health regulation.

Our preference for the BAT approach is primarily normative. We would prefer to prevent injuries to the extent feasible, instead of compensating for them after they occur. Unlike Sunstein, we recognize that workers do not currently receive adequate compensation for their injuries, and we beheve Sunstein's reforms are unlikely to do anything to remedy this problem. We also believe that one can make a moral case for the proposition that society should do the best it can to protect workers, even when the resources devoted to that enterprise exceed the benefits predicted by the "willinguess to pay" measure of value. Altlough Sunstein elegantly defends society's prerogative to use regulation to implement aspirations sucl1 as ours, he seems hesitant to apply these precepts on belialf of workers.

We do not mean to reject Sunstein's proposals out of hand. As an adjunct to technology-based regulation, Sunstein's proposals-including increased workers compensation and injury taxes-could induce additional abatement of toxic substances and result in additional compensa- 
tion of workers. As a substitute for BAT, however, incentive approaches lead to even less regulation and compensation than current levels because they will becoine entangled in case-by-case determinations of "acceptable" levels of risk. Economists have succeeded in exposing the maladies of the technology-based approach for all to see, and from a distance their alternative approach looks better by coinparison. But, as we have demonstrated, the incentive approach also has a considerable number of probleins. Before we abandon BAT for Sunstein's proposals, we advise a closer look at both. 